Marginal Voices 
The Texas Pan American Series 


\title{
Marginal Voices
}

\author{
Selected Stories by \\ Julio Ramón Ribeyro
}

English translation by

Dianne Douglas

Foreword by Dick Gerdes

U UNIVERSITY OF TEXAS PRESS AUSTIN 
Copyright (C) 1993 by the University of Texas Press

All rights reserved

Printed in the United States of America

First edition, 1993

Requests for permission to reproduce material from this work should be sent to

Permissions, University of Texas Press, Box 7819, Austin, Tx 78713-7819.

$@$ The paper used in this publication meets the minimum requirements of American National Standard for Information Sciences-Permanence of Paper for Printed Library

Materials, ANSI Z39.48-I984.

Library of Congress Cataloging-in-Publication Data

Ribeyro, Julio Ramón, date

[Palabra del mudo. English. Selections]

Marginal voices : selected stories / by Julio Ramón Ribeyro ; English translation by Dianne Douglas - ist ed.

p. cm. - (The Texas Pan American Series)

ISBN 0-292-77057-X (alk. paper) — ISBN 0-292-77058-8 (pbk. : alk. paper)

I. Title. II. Series.

PQ8497.R47P3I3 I993

$863-$ dc2o 